\title{
EVALUATION OF THE COUNTERIMMUNOELECTROPHORESIS REACTION AS A SERODIAGNOSIS TEST FOR SWINE LEPTOSPIROSIS
}

\author{
Margareth Élide Genovez ${ }^{1 *}$; Paulo Hideki Yasuda²; Silvio Arruda Vasconcellos ${ }^{3}$; Eliana Scarcelli; \\ Maristela Vasconcellos Cardoso ${ }^{1}$; Raul da Silva Girio ${ }^{4}$
}

\begin{abstract}
${ }^{1}$ Instituto Biológico, Centro de Sanidade Animal, São Paulo, SP, Brasil. ${ }^{2}$ Departamento de Microbiologia, Instituto de Ciências Biomédicas, Universidade de São Paulo-USP, SP, Brasil. ${ }^{3}$ Departamento de Medicina Veterinária Preventiva da Faculdade de Medicina Veterinária, Universidade de São Paulo-USP, SP, Brasil. ${ }^{4}$ Faculdade de Medicina Veterinária, Universidade Estadual de São Paulo-UNESP, Jaboticabal, SP, Brasil
\end{abstract}

Submitted: January 16, 2001; Returned to authors for corrections: April 26, 2001; Approved: May 25, 2001

\begin{abstract}
The Counterimmunoelectrophoresis reaction (CIE) was tested as a genus specific test for swine leptospirosis diagnosis using three soluble extracts obtained from Leptospira sp, serovars pomona, icterohaemorrhagiae and patoc. The extracts were treated with hot Triton X-100 and applied to serum samples of animals divided in three groups: Group 1, 10 swines experimentally infected with the Pomona strain; Group 2, 50 naturally infected swines and Group 3, 10 swines control. These animals were serologically evaluated by CIE and by the Microscopic Agglutination Test (MAT), the WHO reference technique. Groups 1 and 3 were monitored during a period of 93 days after infection (a.i.). Group 1 serum convertion took place around the $10^{\text {th }}$ day a.i. by MAT but ocurred earlier by CIE using any antigen. When CIE was carried out with the homologous antigen to the experimental infection, the results were consistent with MAT, but not when the heterologous antigens were used. Groups 1 and 3 showed distinct results: in Group 3, diferences between results of CIE accomplished with any three antigen extracts were not significant, indicating lack of dependence on the serovar responsible for the outbreak. Although being safe, fast, easy to perform, inexpensive and ideal for analysis of large number of samples, CIE revealed limited genus specificity, which is not convenient for field screening tests. The advantage of CIE is the capability to detect antibodies earlier than MAT.
\end{abstract}

Key words: Counterimmunoelectrophoresis, swine leptospirosis, seradiagnosis

\section{INTRODUCTION}

In swine leptospirosis, abortion is the main clinical evidence. In severe outbreaks, it may be responsible for $100 \%$ of birth losses, affecting economically the property $(4,6)$. The current leptospirosis diagnosis is based on a serological reaction using the Microscopic Aglutination Test (MAT) which is the World Health Organization (WHO) reference test $(2,3)$. As MAT takes long time to reveal the humoral antibodies, presents high contamination risks to the operator and is time-consuming for screening of whole herds, some more modern, faster and preferably genera specific methods have been investigated for the detection of leptospiral antibodies.

Based on the wide use of Counterimmunoelectrophoresis (CIE) for the diagnosis of human infectious diseases $(1,8,9,10,12,13$, 16,17), Terpstra et al. (14), Myers (7) and Yasuda (16) used this technique for the diagnosis of human leptospirosis. The advantage mentioned by these authors is that CIE is able to detect acute infection earlier than MAT, employing only one genus specific antigen.

The purpose of the present paper was to evaluate the applicability and sensitivity of a CIE test for use in swine leptospirosis serodiagnosis, compared to MAT.

\footnotetext{
* Corresponding author. Mailing address: Instituto Biológico, Centro de Sanidade Animal, Av. Conselheiro Rodrigues Alves, 1252. 04014-002, São Paulo,
} SP, Brasil. Telefax: (+5511) 5087-1770 


\section{MATERIALS AND METHODS}

\section{Animal Groups \\ Group 1: Experimentally infected animals}

Ten 70-day old pigs, weighing about $160 \mathrm{Kg}$, clinically healthy and serologically negative by MAT were experimentally inoculated through the intraperitonial route with $4 \mathrm{ml}$ of hamster liver suspension $(1 \% \mathrm{w} / \mathrm{v})$, previously inoculated with the $7^{\text {th }}$ passage of a Pomona strain culture containing 30-40 leptospires/microscopic field $(200 \mathrm{x})$. Serum samples were collected one day before the inoculation and on alternated days between the $3^{\text {rd }}$ and $15^{\text {th }}$ days, every 3 days between the $15^{\text {th }}$ and $39^{\text {th }}$ days and weekly between the $39^{\text {th }}$ and $93^{\text {rd }}$ days after infection (a.i.).

\section{Group 2: Naturally infected animals}

Fifty serum samples were collected from swines involved in an outbreak of leptospirosis characterized by weakness, lack of appetite, fever and jaundice 34 females aborted in the last third of gestation, six of them died and seven had stillbirth.

\section{Group 3: Control group}

Ten swines with the same characteristics as those in Group 1 were used as a negative control group. They were kept under strict hygiene conditions and proper herd management. The serum samples were collected on the first, $44^{\text {th }}$ and $92^{\text {nd }}$ days of the experiment.

\section{Microscopic Agglutination Test (MAT)}

MAT was carried out according to the recommendations of WHO (2,15), using the following living Leptospira sp serovars as antigens: australis, autumnalis, castelonis, bataviae, butembo, canicola, whitcombi, cynopteri, grippotyphosa, hebdomadis, icterohaemorrhagiae, copenhageni, javanica, panama, pomona, pyrogenes, wolffi, hardjo, shermani, tarassovi, patoc. The strains were grown in EMJH (Difco Laboratories-USA) containing 10\% EMJH Enrichment (Difco Laboratories-USA), incubated at $30^{\circ} \mathrm{C}$ for 10 days. Serological reaction at a 1:100 dilution or higher was considered positive, when $50 \%$ of the leptospires were agglutinated. The titer was the highest dilution where $50 \%$ of the leptospires still agglutinated.

\section{CIE Reaction}

Three Leptospira sp serovars were chosen to be used as antigen extract in the CIE test: pomona (Pomona strain), icterohaemorrhagiae (RGA strain) and patoc (Patoc-1 strain). RGA and Patoc-1 strains were selected because they are the most prevalent serovars in swines and can be transmitted to humans, playing an important role in public health. Patoc is the most studied serovar of L. biflexa used in several genus specific tests, presenting good agreement with MAT results for human leptospirosis diagnosis. The Pomona, RGA and Patoc-1 strains were grown in EMJH containing 10\% EMJH Enrichment incubated at $30^{\circ} \mathrm{C}$ for 10 days. The antigen extract from these strains was obtained as described by Myers (7), with some modifications. Briefly, each strain was grown in $250 \mathrm{ml}$ of medium and harvested by centrifugation at $11,000 \mathrm{x} \mathrm{g}$ for $15 \mathrm{~min}$. The pellet was treated with $10 \mathrm{ml}$ Triton X-100 (4\%) in $0.01 \mathrm{M}$ PBS, $\mathrm{pH} 7.2$ and heated in a water bath for $4 \mathrm{~h}$ at $50^{\circ} \mathrm{C}$, with periodic shaking. This suspension was centrifuged at 11,000 x $\mathrm{g}$ for 20 min. The supernatant was preserved with sodium azide $(1 \%)$. The antigens were titrated by doubling dilutions in PBS against a positive swine serum reactive by MAT to pomona $(51,200)$, butembo $(6,400)$, autumnalis $(1,600)$, icterohaemorrhagiae (400), pyrogenes (400), hardjo (200), wolffi (100) and patoc serovars (100). They were also titrated against a MAT negative serum sample, collected from an apparently healthy swine. The working antigen consisted of 1:4 dilution. Glass slides ( 75 x 50 $\mathrm{mm}$ ) were covered with $8 \mathrm{ml}$ of $0.9 \%$ melted agarose, type II (Sigma-Aldrich Co-USA) in 0.05 M Tris $\mathrm{HCl}$ buffer, $\mathrm{pH}$ 7.5. After gelling at room temperature, the slides were placed at $4^{\circ} \mathrm{C}$ for a few minutes. A template was placed under each slide and three double parallel rows of three wells each ( $2 \mathrm{~mm}$ diameter) were drilled, each pair separated by a distance of $5 \mathrm{~mm}$. The distance between each row was $5 \mathrm{~mm}$. In the first stage, the wells corresponding to the anode were filled with undiluted sera and a constant eletric current ( $6 \mathrm{~mA} /$ slide $)$ was applied to each side of the slide for $30 \mathrm{~min}$, at a potential difference of 10 $\mathrm{V}$, with the same buffer. Connecting filter-paper was placed on both ends of the slide. Subsequently, the cathode side of slide was filled with the antigen, and the run was continued for aditional 90 minutes. After in a wet chamber for 24 hours, the slides were washed with PBS buffer $\mathrm{pH} 7.2$, stained with Starch Schwartzs $10 \mathrm{~B}$ at $0.5 \% \mathrm{w} / \mathrm{v}$ in acetic acid $1 \%$ for $5 \mathrm{~min}$. and destained with acetic acid 5\%. The positive sera showed one or more precipitation bands between the cathode and anode wells. In the second stage, the serum samples were diluted in PBS buffer, pH 7.2 in serial two fold up to 1:32 and submitted to the process described above. The end point titer was the highest dilution presenting one or more bands. The antigen and serum specificity reaction were investigated against PBS buffer. Positive and negative control serum samples were included in each run.

\section{RESULTS}

Before inoculation, all animals in Group 1 were negative by MAT. After inoculation, none of the animals showed any clinical signs of leptospirosis, but became reactive to pomona serovar (Table 1). The serum convertion took place around the $10^{\text {th }}$ day (sd $\pm 1)$ a.i. and the titers ranged from 100 to 6,400 by $\operatorname{MAT}(X=1,600$, $\mathrm{sd} \pm 1,117.1$ ) reaching the peak on 22.7 days ( $\mathrm{sd} \pm 6.9$ days.). On the $93^{\text {rd }}$ day a.i. $50 \%$ of Group 1 swines were negative.

By CIE, no unespecific reaction was observed in the three extract antigens or in negative and positive control serum samples. 
Table 1. Microscopic Agglutination Test (MAT) titers using Leptospira sp serovar pomona as antigen on serum samples from swines experimentally infected with Pomona strain (Group 1). São Paulo, 2000.

\begin{tabular}{|c|c|c|c|c|c|c|c|c|c|c|c|c|}
\hline \multirow[t]{2}{*}{ D.A.I. } & \multicolumn{10}{|c|}{ Animal Identification } & \multirow[t]{2}{*}{$\mathrm{X}$} & \multirow[t]{2}{*}{$\mathrm{sd}$} \\
\hline & 1 & 2 & 3 & 4 & 5 & 6 & 7 & 8 & 9 & 10 & & \\
\hline 0 & $\mathrm{~N}$ & $\mathrm{~N}$ & $\mathrm{~N}$ & $\mathrm{~N}$ & $\mathrm{~N}$ & $\mathrm{~N}$ & $\mathrm{~N}$ & $\mathrm{~N}$ & $\mathrm{~N}$ & $\mathrm{~N}$ & 0 & 0 \\
\hline 3 & $\mathrm{~N}$ & $\mathrm{~N}$ & $\mathrm{~N}$ & $\mathrm{~N}$ & $\mathrm{~N}$ & $\mathrm{~N}$ & $\mathrm{~N}$ & $\mathrm{~N}$ & $\mathrm{~N}$ & $\mathrm{~N}$ & 0 & 0 \\
\hline 5 & $\mathrm{~N}$ & $\mathrm{~N}$ & $\mathrm{~N}$ & $\mathrm{~N}$ & $\mathrm{~N}$ & $\mathrm{~N}$ & $\mathrm{~N}$ & $\mathrm{~N}$ & $\mathrm{~N}$ & $\mathrm{~N}$ & 0 & 0 \\
\hline 7 & $\mathrm{~N}$ & $\mathrm{~N}$ & $\mathrm{~N}$ & $\mathrm{~N}$ & $\mathrm{~N}$ & $\mathrm{~N}$ & $\mathrm{~N}$ & $\mathrm{~N}$ & $\mathrm{~N}$ & $\mathrm{~N}$ & 0 & 0 \\
\hline 9 & 100 & 100 & 400 & $\mathrm{~N}$ & $\mathrm{~N}$ & $\mathrm{~N}$ & 200 & $\mathrm{~N}$ & 200 & $\mathrm{~N}$ & 100 & 126.5 \\
\hline 11 & 200 & 200 & 400 & 400 & 100 & 400 & 200 & 400 & 1600 & 1600 & 550 & 535.2 \\
\hline 13 & 800 & 1600 & 800 & 400 & 400 & 400 & 200 & 400 & 3200 & 1600 & 980 & 878.4 \\
\hline 15 & 1600 & 1600 & 800 & 800 & 400 & 400 & 400 & 400 & 3200 & 1600 & 1120 & 854.2 \\
\hline 18 & 1600 & 1600 & 3200 & 800 & 400 & 400 & 400 & 400 & 3200 & 1600 & 1360 & 1046.1 \\
\hline 21 & 3200 & 1600 & 800 & 800 & 400 & 3200 & 400 & 400 & 3200 & 1600 & 1560 & 1151.7 \\
\hline 24 & 1600 & 3200 & 800 & 800 & 3200 & 800 & 400 & 400 & 3200 & 1600 & 1600 & 1117.1 \\
\hline 27 & 1600 & 800 & 800 & 800 & 400 & 800 & 400 & 100 & 6400 & 1600 & 1370 & 1737.8 \\
\hline 30 & 1600 & 800 & 800 & 800 & 800 & 800 & 400 & $\mathrm{~N}$ & 3200 & 3200 & 1240 & 1050.0 \\
\hline 33 & 800 & 800 & 200 & 800 & 800 & 800 & 400 & $\mathrm{~N}$ & 3200 & 800 & 860 & 829.7 \\
\hline 36 & 800 & 800 & 100 & 1600 & 800 & 800 & 400 & $\mathrm{~N}$ & 3200 & 400 & 890 & 881.4 \\
\hline 39 & 800 & 800 & 100 & 1600 & 800 & 800 & 200 & $\mathrm{~N}$ & 1600 & 400 & 710 & 533.8 \\
\hline 44 & 800 & 800 & 100 & 800 & 800 & 400 & 100 & $\mathrm{~N}$ & 1600 & 400 & 580 & 457.8 \\
\hline 51 & 400 & 800 & 100 & 200 & 200 & 400 & 100 & $\mathrm{~N}$ & 400 & 400 & 300 & 219.1 \\
\hline 58 & 400 & 100 & 100 & 200 & 100 & 200 & 100 & $\mathrm{~N}$ & 200 & 400 & 180 & 124.9 \\
\hline 65 & 400 & 100 & 100 & 200 & $\mathrm{~N}$ & 200 & $\mathrm{~N}$ & $\mathrm{~N}$ & 200 & 200 & 140 & 120.0 \\
\hline 72 & 200 & 100 & 100 & 200 & $\mathrm{~N}$ & 100 & $\mathrm{~N}$ & $\mathrm{~N}$ & 200 & 200 & 110 & 83.1 \\
\hline 79 & 200 & 100 & $\mathrm{~N}$ & 200 & $\mathrm{~N}$ & 100 & $\mathrm{~N}$ & $\mathrm{~N}$ & 200 & 200 & 100 & 89.4 \\
\hline 86 & 200 & 100 & $\mathrm{~N}$ & 200 & $\mathrm{~N}$ & 100 & $\mathrm{~N}$ & $\mathrm{~N}$ & 200 & 100 & 90 & 83.1 \\
\hline 93 & 100 & 100 & $\mathrm{~N}$ & 100 & $\mathrm{~N}$ & $\mathrm{~N}$ & $\mathrm{~N}$ & $\mathrm{~N}$ & 100 & 100 & 50 & 50.0 \\
\hline
\end{tabular}

D.A.I. = Day after infection; $\mathrm{N}=$ negative; $\mathrm{X}=$ MAT titers geometric mean, expressed as the reciprocal of the serum dilution; $\mathrm{sd}=$ standart deviation.

The results of undiluted serum samples from Group 1, submitted to CIE using Pomona extract as antigen are shown in Table 2. The precipitating antibodies could be detected in 5.1 days (sd \pm 1.9 days) a.i.. Around the $7^{\text {th }}$ day a.i., $90 \%$ of the samples were positive, while by MAT they were still negative. On the $9^{\text {th }}$ day a.i., positivity of CIE reached $100 \%$ and $50 \%$ by MAT. Only from the $11^{\text {th }}$ to $13^{\text {th }}$ days a.i., CIE and MAT were equivalent. Positive and negative irregular responses by CIE was observed from the $19.6^{\text {th }}$ days ( $(\mathrm{sd} \pm 5.9$ days) a.i. to the end of the experimental period.

The precipitating antibody titers did not correlate with agglutinating ones. From the $5^{\text {th }}$ to $9^{\text {th }}$ day a.i., the results by CIE with Pomona extract after the sera dilution were similar to those with undiluted sera (Table 3 ). CIE showed $100 \%$ positive reactions from the $9^{\text {th }}$ to $27^{\text {th }}$ day a.i., the same as MAT. The positive result increase was observed during the period when serologic responses by CIE with undiluted sera were irregular, prior to the peak of agglutinating antibodies.

The CIE precipitating antibodies could be first detected by RGA extract in undiluted serum samples of four animals only, but they were irregular until the end of the experimental period. Even after dilution, the results disagreed with those by MAT. Similarly to the RGA extract, the Patoc- 1 extract didn't present regular precipitating bands and was also in desagreement with MAT.

Statistic Cochran Q test (12) showed disagreement between MAT and CIE responses with Pomona, RGA and Patoc- 1 extracts, with undiluted and diluted Group 1 sera, respectively (Qui Square $=65.85$ and 19.5; critic $\mathrm{Q}$ Square $=7.82 ; \mathrm{p} \leq 0.05$ ). Through the correlation of the multiple squares study; the sensitivity increase obtained with the sera dilution was significant (Qui Square $=38.2$; critic Qui Square $=3.84 ; \mathrm{p} \leq 0.05$ ).

Among 50 serum samples of Group 3, 48 (96\%) were positive by MAT to Leptospira sp, serovars pomona 50\% (24/48) and icterohaemorrhagiae $39.6 \%$ (19/48). Titers ranged from 100 to 51,200 , and five samples were positive to both serovars at the same titer. By CIE, 40/50 samples were positive to the RGA, 33/ 50 to the Pomona and 39/50 to the Patoc-1 extracts. Only two serum samples were negative by MAT. One of them was positive to RGA and Patoc-1 extracts, but negative to Pomona extract by 
Table 2. Counterimmunoelectrophoresis (CIE) results using Pomona strain (pomona serovar) extract as antigen on undiluted serum samples from swines experimentally infected with Pomona strain. São Paulo (Group 1), 2000.

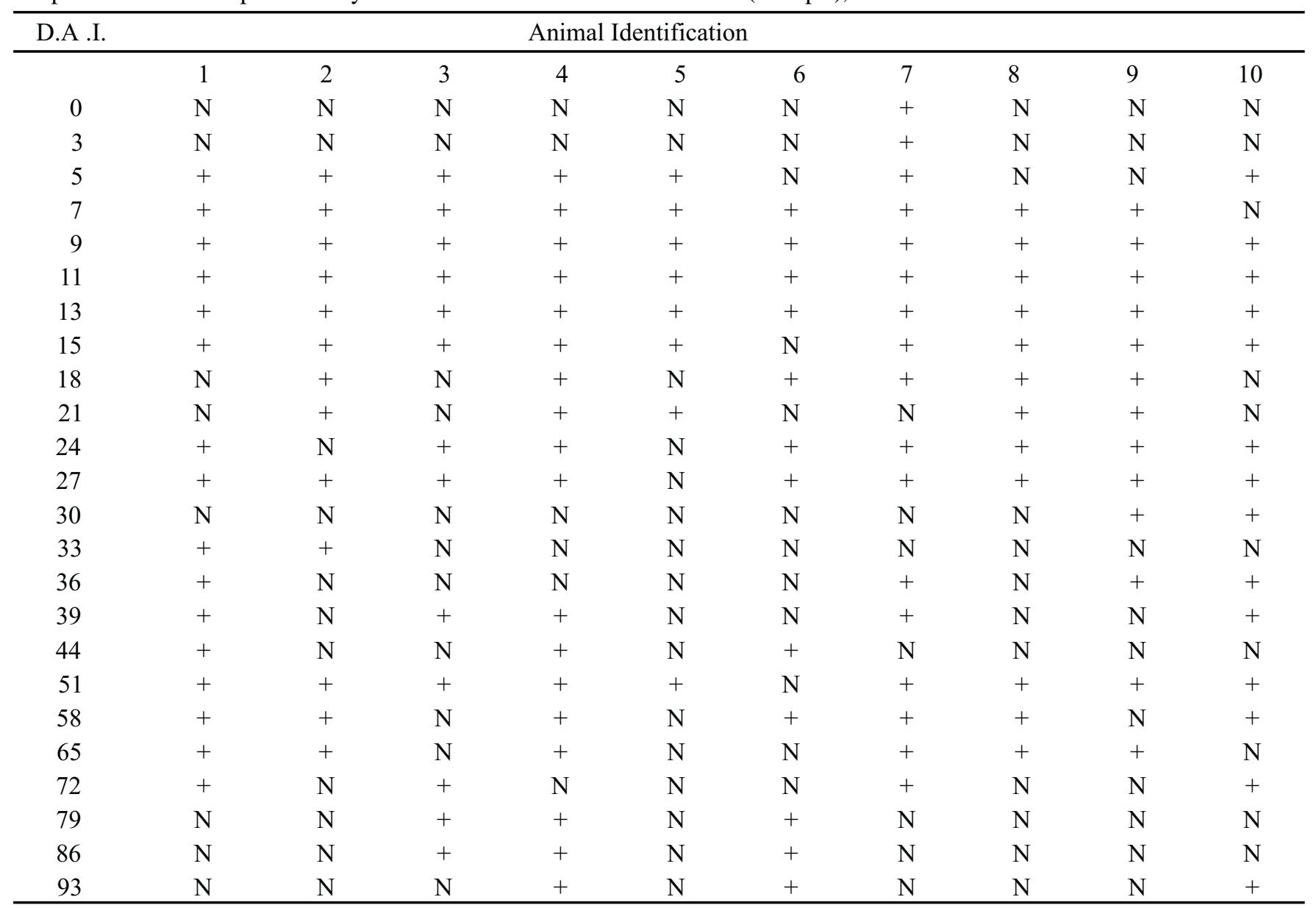

D.A.I. $=$ Day after infection; $\mathrm{N}=$ negative $;+=$ positive.

CIE. The other serum sample was negative to the three extracts. In this group, the Cochran $\mathrm{Q}$ test showed agreement among the CIE responses to any three antigen extracts (Qui Square $=5.21$; critic Qui Square $=5.99, \mathrm{p} \leq 0.05$ ).

The sensitivity, specificity, agreement, positive and negative false and positive and negative preditive values (5) for Group 1 and Group 3, comparing CIE and MAT results, are presented in Tables 4 and 5 .

All the control group serum samples were negative by MAT with all serovars listed. Three animals reacted weakly to Pomona extract on the $44^{\text {th }}$ day by CIE, but all the others were negative to the three antigens during all experimental period.

\section{DISCUSSION}

The CIE using homologous antigen to experimental infection showed earlier responses than MAT, but presented irregular positive and negative responses during the experimental period. As these inconsistent and variable responses were observed in the experimental period prior to the peak of agglutinins and at the end of the experiment ( 93 days), the possible occurrence of prozone phenomenon was raised. As CIE is a semiquantitative test, this hippotesis can not be proved. But, when the sera were submitted to dilution and titer evaluation, these irregular responses almost disappeared, reaching results equivalent to MAT. As Yasuda (16) had already stated, no correlation between MAT and CIE test titers was observed either. These results were not in agreement with Terpstra (14) who showed ascendent titers in CIE, presenting discrepancy only with weakly reactive sera, even though a limited number of paired samples was evaluated. The statistic analysis of the results obtained by CIE test with Pomona extract in Group 1 diluted serum samples and by MAT with pomona serovar showed significant agreement between them and any 
Table 3. Counterimmunoelectrophoresis (CIE) titers using Pomona strain (pomona serovar) extract as antigen on diluted serum samples from swines experimentally infected with Pomona strain (Group1) São Paulo, 2000.

\begin{tabular}{ccccccccccccc}
\hline D.A .I. & \multicolumn{1}{c}{} & \multicolumn{1}{c}{ Animal Identification } & & & & X & sd \\
\hline & 1 & 2 & 3 & 4 & 5 & 6 & 7 & 8 & 9 & 10 & & \\
\hline 0 & $\mathrm{~N}$ & $\mathrm{~N}$ & $\mathrm{~N}$ & $\mathrm{~N}$ & $\mathrm{~N}$ & $\mathrm{~N}$ & 1 & $\mathrm{~N}$ & $\mathrm{~N}$ & $\mathrm{~N}$ & 0.1 & 0.3 \\
3 & $\mathrm{~N}$ & $\mathrm{~N}$ & $\mathrm{~N}$ & $\mathrm{~N}$ & $\mathrm{~N}$ & $\mathrm{~N}$ & 1 & $\mathrm{~N}$ & $\mathrm{~N}$ & $\mathrm{~N}$ & 0.1 & 0.3 \\
5 & 8 & 1 & 4 & 1 & 2 & $\mathrm{~N}$ & 4 & $\mathrm{~N}$ & $\mathrm{~N}$ & 1 & 2.1 & 2.4 \\
7 & 8 & 4 & 8 & 1 & 1 & 4 & 8 & 4 & 4 & $\mathrm{~N}$ & 4.2 & 2.8 \\
9 & 8 & 8 & 2 & 1 & 1 & 4 & 4 & 1 & 8 & 8 & 3.0 & 4.5 \\
11 & 8 & 8 & 4 & 1 & 4 & 2 & 4 & 4 & 2 & 8 & 4.5 & 2.5 \\
13 & 4 & 8 & 8 & 1 & 2 & 2 & 8 & 1 & 2 & 2 & 3.8 & 2.8 \\
15 & 4 & 2 & 2 & 1 & 8 & 2 & 4 & 4 & 8 & 2 & 3.7 & 2.4 \\
18 & 8 & 4 & 8 & 1 & 2 & 1 & 2 & 1 & 8 & 16 & 5.1 & 4.6 \\
21 & 8 & 4 & 16 & 1 & 2 & 2 & 8 & 4 & 8 & 4 & 5.7 & 4.2 \\
24 & 8 & 4 & 8 & 1 & 4 & 2 & 2 & 4 & 8 & 8 & 4.9 & 2.7 \\
27 & 8 & 2 & 4 & 1 & 4 & 1 & 8 & 4 & 16 & 8 & 5.6 & 4.3 \\
30 & 8 & 4 & 2 & $\mathrm{~N}$ & $\mathrm{~N}$ & $\mathrm{~N}$ & 4 & $\mathrm{~N}$ & 8 & 8 & 3.4 & 3.4 \\
33 & 4 & 8 & 8 & 1 & 2 & 2 & 8 & $\mathrm{~N}$ & 4 & 8 & 4.5 & 3.1 \\
36 & 4 & 4 & 4 & $\mathrm{~N}$ & 2 & 2 & 8 & $\mathrm{~N}$ & 8 & 8 & 4.0 & 3.0 \\
39 & 4 & 2 & 4 & 2 & 2 & 2 & 8 & $\mathrm{~N}$ & 8 & 4 & 3.6 & 2.5 \\
44 & 4 & 2 & 4 & 2 & $\mathrm{~N}$ & 2 & 4 & $\mathrm{~N}$ & 8 & 4 & 3.0 & 2.2 \\
51 & 4 & 4 & 4 & 2 & 2 & $\mathrm{~N}$ & 8 & 1 & 4 & 2 & 3.1 & 2.1 \\
58 & 8 & 2 & 8 & 1 & $\mathrm{~N}$ & 2 & 8 & 1 & 4 & 2 & 3.6 & 3.0 \\
65 & 4 & 2 & 8 & 1 & $\mathrm{~N}$ & $\mathrm{~N}$ & 8 & 1 & 4 & $\mathrm{~N}$ & 2.8 & 3.0 \\
72 & 8 & 2 & 8 & $\mathrm{~N}$ & $\mathrm{~N}$ & 2 & 2 & $\mathrm{~N}$ & 4 & 1 & 2.7 & 2.9 \\
79 & $\mathrm{~N}$ & $\mathrm{~N}$ & 8 & 1 & 2 & 2 & $\mathrm{~N}$ & $\mathrm{~N}$ & $\mathrm{~N}$ & $\mathrm{~N}$ & 1.3 & 2.4 \\
86 & $\mathrm{~N}$ & $\mathrm{~N}$ & 4 & 1 & $\mathrm{~N}$ & 2 & $\mathrm{~N}$ & $\mathrm{~N}$ & $\mathrm{~N}$ & $\mathrm{~N}$ & 0.7 & 1.3 \\
93 & $\mathrm{~N}$ & $\mathrm{~N}$ & $\mathrm{~N}$ & 1 & $\mathrm{~N}$ & 1 & $\mathrm{~N}$ & $\mathrm{~N}$ & $\mathrm{~N}$ & 1 & 0.3 & 0.3 \\
\hline
\end{tabular}

D.A.I. $=$ Day after infection; $\mathrm{N}=$ negative; $\mathrm{X}=\mathrm{CIE}$ titers geometric mean, expressed as the reciprocal of the serum dilution; sd $=$ standart deviation.

Table4. Serologic evaluation by CIE, taking MAT as reference, applied on Group 1 diluted (D) and undiluted (UD) serum samples from swines experimentally infected with Pomona strain. São Paulo, 2000.

\begin{tabular}{|c|c|c|c|c|c|c|}
\hline & \multicolumn{2}{|c|}{ Pomona (\%) } & \multicolumn{2}{|c|}{$\begin{array}{c}\text { Icterohaemorrhagiae } \\
(\%) \\
\end{array}$} & \multicolumn{2}{|c|}{ Patoc-1 (\%) } \\
\hline & ND & D & ND & D & ND & D \\
\hline rS & 62.7 & 87.6 & 50.3 & 63.9 & 41.4 & 65.1 \\
\hline rE & 56.3 & 54.9 & 69.0 & 3 & 69.0 & 46.5 \\
\hline A & 60.8 & 77.9 & 55.8 & 59.6 & 49.6 & 59.6 \\
\hline$+F$ & 43.7 & 45.1 & 31.0 & 50.7 & 31.0 & 53.5 \\
\hline$-F$ & 37.3 & 12.4 & 49.7 & 36.1 & 58.6 & 34.9 \\
\hline$+\mathrm{PV}$ & 77.4 & 82.2 & 79.4 & 75.0 & 76.1 & 74.3 \\
\hline -PV & 38.8 & 65.0 & 36.8 & 36.4 & 33.1 & 35.9 \\
\hline
\end{tabular}

rS: relative sensitivity; rE: relative especificity; A: agreement; $\mathrm{F}+/$ : false positive/negative results; PV+/-: positive/negative preditive values.

discrepancy was considered casual. The serum dilution effect over the relative sensitivity was statistically significant, but with the occurrence of some loss of specificity.
When CIE was carried out with the homologous antigen to the experimental infecction, consistent results with MAT were obtained, but not when the two heterologous antigens were used.

In Group 3, the diferences among the results of the CIE accomplished with all three antigen extracts were not significant, indicating lack of dependence on the serovar responsible for the outbreak. As only two serum samples were negative by MAT, the discrepancy between the specificity of two tests could be casual or due to the CIE capacity to detect antibodies earlier than MAT.

Some factors could explain the different results in the two animal groups. The difference between primary and secondary antibody responses and the maturation level of the antibody production cells, which are dependent on the antigen dose the animal was exposed to, are certainly (11).

Although being safe, fast, easy to perform; inexpensive and ideal for analysis of large number of samples (1), CIE revealed limited genus specificity, which is not convenient for field screening tests. Other types of antigen extracts should be tested for this purpose. However, CIE is advantageous because is able to detect antibodies earlier than MAT. 
Table 5. Serologic evaluation by CIE, taking MAT as reference, applied on Group 3 serum samples from naturally infected swines .São Paulo, 2000.

\begin{tabular}{|c|c|c|c|}
\hline \multicolumn{2}{|c|}{ Pomona (\%) } & $\begin{array}{c}\text { Icterohaemorrhagie } \\
(\%)\end{array}$ & Patoc-1 (\%) \\
\hline $\mathrm{rS}$ & 68.8 & 81.2 & 79.2 \\
\hline $\mathrm{rE}$ & 100 & 50 & 50 \\
\hline A & 70 & 80 & 78 \\
\hline$+F$ & 0 & 50 & 50 \\
\hline$-F$ & 31.2 & 18.8 & 21 \\
\hline$+\mathrm{PV}$ & 100 & 97.5 & 97.4 \\
\hline -PV & 11.8 & 10 & 9.1 \\
\hline
\end{tabular}

rS: relative sensitivity; rE: relative especificity; A: agreement; $\mathrm{F}+/$-: false positive/negative results; $\mathrm{PV}+/$-: positive/negative preditive values.

\section{RESUMO}

\section{Avaliação da reação de contraimunoeletroforese como teste sorológico para diagnóstico da leptospirose suína}

Avaliou-se a reação de contraimunoeletroforese (CIE) como teste gênero-específico para diagnóstico da leptospirose suína, usando-se três extratos solúveis de Leptospira sp, sorovares pomona, icterohaemorrhagiae e patoc, obtidos pelo tratamento com Triton X-100 a quente e aplicados a amostras de soro de suínos subdivididos em três grupos: Grupo 1, 10 suínos experimentalmente infectados com estirpe Pomona; Grupo 2, 50 suínos naturalmente infectados e Grupo 3, controle. As amostras de soros foram submetidas à reação de CIE e os resultados comparados aos da Soroaglutinação Microscópica (SAM), técnica de referência pela WHO. Os Grupos 1 e 3 foram monitorados por 93 dias após a inoculação (p.i.). Pela SAM a soroconversão do Grupo 1 ocorreu por volta do $10^{\circ}$ dia p.i., enquanto pela CIE, empregando-se qualquer extrato antigênico, foi anterior à SAM. Quando a CIE foi realizada frente a antigeno homólogo à infecção, seus resultados foram equivalentes aos da SAM, não se verificando o mesmo frente aos antígenos heterólogos. Neste aspecto, os Grupos 1 e 3 mostraram comportamento diferente pois não houve diferença significativa entre os resultados da CIE frente aos três antígenos, o que poderia significar serem independentes do sorovar responsável pelo surto ou infectante. Embora a CIE seja segura, rápida, de fácil execução, de baixo custo e ideal para análise em grande escala de amostras, revelou-se de limitada capacidade gênero-específica, o que não é desejavel para testes de triagem de campo; mas poderia ser útil na detecção precoce de resposta sorológica em relação à SAM.

Palavras-chave: Contraimunoeletroforese, leptospirose suína, sorodiagnóstico

\section{REFERENCES}

1. Draper, C.C. The use of counterimmunoelectrophoresis in immunodiagnosis. Trans. R. Soc. Trop. Med. Hyg., 70:93-97, 1976.

2. Faine, S. Guidelines for the control of leptospirosis. WHO (World Health Organization) Offset Publ., 67:1-171, 1982.

3. Faine, S. Leptospira and leptospirosis. CRC Press, Inc.USA., 1994, $353 \mathrm{p}$.

4. Fergson, C. In: Diseases of Swine. 3.ed. ED. H.W. Dunne. Ames, Iowa State University Press, USA, 1970, p.416.

5. Galen, R.S.; Gambino, R.S. Beyond normality: the predictive value and efficiency of medical diagnosis, 1975, 237p. New York. Eds. John Wiley \& Sons, USA.

6. Kemenes, F.; Suveges, T. Leptospira induced repeated abortion in sows. Acta Vet. Acad. Sci. Hung., 26:395-403, 1976.

7. Myes, D.M. Serodiagnosis of human leptospirosis by counterimmunoelectrophoresis. J. Clin. Microbiol., 25:897-899, 1987.

8. Muratori, L.; Cataleta, M.; Muratori, P.; Lenzi, M.; Bianchi, F.B. Liver/kidney microsomal antibody type 1 and liver cytosol antibody type 1 concentrations in type autoimmune hepatitis. Gut, 42: 721726, 1988.

9. Parodi, A.; Drosera, M.; Barbieri, L.; Rebora, A. Counterimmunoelectrophoresis, ELISA and immunoblotting detection of anti-RO/SSA antibodies in subacute cutaneous lupus erytrematosus. A comparative study. Br.J.Dermatol., 138:114-7, 1998.

10. Ravinder, P.T.; Parija, S.C. Counterimmunoelectrophoresis test for detection of hidatid antigen in fluid from hydatid cysts: a preliminary report. Acta Trop., 66:169-73, 1997.

11. Roitt, I.; Brostoff, J.; Male, D. Imunologia Ed. Manole. São Paulo, SP, 1989.

12. Siegel, S. Estadistica no paramétrica aplicada a las ciencias de la conducta. México. Eds. Trillas, 1975, p.86-195.

13. Sharma, M.; Datta, U.; Roy, P.; Verma, S.; Sehgal, S. Low sensitivity of counter-current immuno-electrophoresis for serodiagnosis of typhoid fever. J. Med Microbiol, 46:1039-42, 1997.

14. Terpstra, W.J.; Schoone, G.J.; Lithart, G.S. Counterimmunoelectroforesis in the diagnosis of human leptospirosis. Zentralbl. Bakteriol. Mikrobiol. Hyg. ABT. 1. Orig.A., 244:285-90, 1979.

15. Vasconcellos, S.A. Diagnóstico da leptospirose em suinos experimentalmente infectados com Leptospira interrogans sorotipo pomona. emprego da reação de soroaglutinação microscópica tendo como antígeno a Leptospira biflexa, estírpe Buenos Aires. São Paulo, 1986. (Thesis. Faculdade de Medicina Veterinária e Zootecnia-USP).

16. Yasuda, P.H. Avaliação da contraimunoeletroforese com antígenos dos sorotipos icterohaemorrhagiae e patoc no diagnóstico sorológico da leptospirose humana. São Paulo, 1989. (Thesis. Instituto de Ciências Biomédicas-USP.

17. Zalatnai, A.; Zala, J.; Sandor, G. Coccidiomycosis in Hungary. The first import case. Pathol. Oncol. Res., 4:147-51, 1998. 